\title{
WY-14643 and 9-cis-retinoic acid induce IRS-2/PI 3-kinase signalling pathway and increase glucose transport in human skeletal muscle cells: differential effect in myotubes from healthy subjects and Type 2 diabetic patients
}

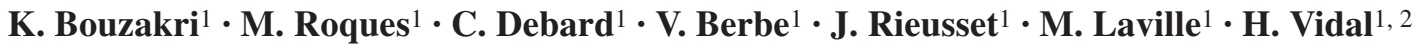 \\ ${ }^{1}$ INSERM U449/INRA U1235 and Human Nutrition Research Center of Lyon, R. Laennec Medical Faculty, \\ Claude Bernard University of Lyon, Lyon, France \\ 2 INSERM U449, Faculté de Médecine RTH Laennec, Lyon Cedex, France
}

\section{Abstract}

Aims/hypothesis. To determine the effects of peroxisome proliferator-activated receptor $\alpha(\operatorname{PPAR} \alpha)$ and retinoid $\mathrm{X}$ receptor (RXR) agonists on insulin action, we investigated the effects of Wy-14643 and 9-cisretinoic acid (9-cis-RA) on insulin signalling and glucose uptake in human myotubes.

Methods. Primary cultures of differentiated human skeletal muscle cells, established from healthy subjects and Type 2 diabetic patients, were used to study the effects of Wy-14643 and 9-cis-RA on the expression and activity of proteins involved in the insulin signalling cascade. Glucose transport was assessed by measuring the rate of $\left[{ }^{3} \mathrm{H}\right] 2$-deoxyglucose uptake.

Results. Wy-14643 and 9-cis-RA increased IRS-2 and $\mathrm{p} 85 \alpha$ phosphatidylinositol 3-kinase (PI 3-kinase) mRNA and protein expression in myotubes from nondiabetic and Type 2 diabetic subjects. This resulted in increased insulin stimulation of protein kinase B phos- phorylation and increased glucose uptake in cells from control subjects. Myotubes from diabetic patients displayed marked alterations in the stimulation by insulin of the IRS-1/PI 3-kinase pathway. These alterations were associated with blunted stimulation of glucose transport. Treatment with $\mathrm{Wy}-14643$ and 9-cis-RA did not restore these defects but increased the basal rate of glucose uptake.

Conclusions/interpretation. These results demonstrate that PPAR $\alpha$ and RXR agonists can directly affect insulin signalling in human muscle cells. They also indicate that an increase in the IRS-2/PI 3-kinase pathway does not overcome the impaired stimulation of the IRS-1-dependent pathway and does not restore insulin-stimulated glucose uptake in myotubes from Type 2 diabetic patients.

Keywords Fibrates - Gene expression - Glucose uptake - Insulin resistance - Insulin signalling · Nuclear receptors $\cdot$ PI 3-kinase $\cdot$ Rexinoids
Received: 11 November 2003 / Accepted: 10 March 2004 Published online: 26 June 2004

(C) Springer-Verlag 2004

H. Vidal $(\bowtie)$

INSERM U449, Faculté de Médecine RTH Laennec, 69370 Lyon Cedex 08, France

E-mail: vidal@laennec.univ-lyon1.fr

Tel.: +33-4-78778629, Fax: +33-4-78778762

Abbreviations: PI 3-kinase, phosphatidylinositol 3-kinase . PKB, protein kinase B · PKC, protein kinase C .

PPAR, peroxisome proliferator-activated receptor .

9-cis-RA, 9-cis-retinoic acid $\cdot \mathrm{RXR}$, retinoid X receptor

\section{Introduction}

The major metabolic disturbance associated with Type 2 diabetes mellitus is insulin resistance [1]. This defect develops at an early stage of the disease, before the onset of diabetes [2]. The main characteristic of insulin resistance is a strong reduction of insulininduced glucose utilisation in skeletal muscle [1]. A number of studies have demonstrated that stimulation of phosphatidylinositol 3-kinase (PI 3-kinase) activity by insulin in the muscle of Type 2 diabetic patients is altered [3, 4, 5, 6, 7]. Because the PI 3-kinase pathway plays a central role in the metabolic effects of insulin, notably in the translocation of glucose transporters [8, 9], impaired PI 3-kinase activity in muscle might be 
one of the causes of insulin resistance in Type 2 diabetes [10].

The PI 3-kinases involved in insulin action act as heterodimers generally composed of a p85 regulatory subunit and a p110 catalytic subunit [9]. The catalytic subunits, p110 $\alpha$ and $\beta$, are thought to be the main isoforms involved in insulin action [9]. We recently reported that the mRNA expression of these two proteins is not altered in the skeletal muscle of Type 2 diabetic patients [11]. The p85 regulatory subunit is an adapter molecule that activates the p110 subunits through the interaction of its Src homology 2 domains with specific phosphorylated tyrosine residues of IRSs $[8,9]$.

Alteration in the protein or mRNA levels of $\mathrm{p} 85 \alpha$ PI 3-kinase is generally not observed in the muscle of Type 2 diabetic subjects $[3,4,5,11,12]$. However, the protein amount of $\mathrm{p} 85 \alpha$ PI 3-kinase is reduced in the skeletal muscle of insulin-resistant obese individuals [13]. Moreover, modification of the quantity of the p85 $\alpha$ PI 3-kinase in rodent tissues, either by transgenesis [14] or by adenovirus-mediated overexpression [15], led to important changes in insulin sensitivity. These data collectively suggest that PI 3-kinase can be a pharmacological target for the treatment of insulin resistance.

In agreement with this, we found that the new antidiabetic drug rosiglitazone [16] induced the expression of $\mathrm{p} 85 \alpha$ PI 3-kinase in isolated human adipocytes [17]. This effect was associated with increased insulin-induced PI 3-kinase and protein kinase B (PKB) activities and with a significant improvement of the antilipolytic action of the hormone [17]. Due to very low expression of the thiazolidinedione receptor peroxisome proliferator-activated receptor (PPAR) $\gamma$ in skeletal muscle, this insulin-sensitising effect of rosiglitazone was not be observed in human muscle cells [18]. However, by testing the possible role of other nuclear receptors of the same family, we found that the combination of Wy-14643 and 9-cis retinoic acid (9-cis-RA) induced p85 $\alpha$ PI 3-kinase expression and potentiated insulin activation of PI 3-kinase activity in human myotubes [18]. Wy-14643 is a potent activator of PPAR $\alpha$ in rodents and 9-cis-RA is a ligand of retinoid X receptor (RXR), suggesting that activation of the heterodimer PPAR $\alpha / R X R$ in skeletal muscle could improve insulin sensitivity [18]. Recent reports showing the beneficial effect of treatment with PPAR $\alpha$ [19] or with RXR [20] agonists in insulin-resistant rodents support this hypothesis.

To gain more insight into the action of Wy-14643 and 9-cis-RA on insulin action in muscle, we investigated in this study the effects of theses two molecules on the expression and activity of the main components of the insulin signalling pathways and on glucose uptake in differentiated human skeletal muscle cells obtained from healthy subjects and Type 2 diabetic patients. Primary cultures of human muscle cells display numerous features of mature skeletal muscle [21, 22]. More importantly, myotubes established from Type 2 diabetic patients conserve the diabetic phenotype, including decreased insulin responsiveness of glucose uptake and glycogen synthase activation [21, 23, 24, $25,26,27]$, as well as altered insulin stimulation of PI 3 -kinase activity $[26,28]$. These cell cultures are thus a relevant and interesting model to verify whether and how drug treatments could improve insulin action in human muscle cells.

\section{Subjects and methods}

Products. Wy-14643 was obtained from Biomol Research Laboratories (Plymouth Meeting, Pa., USA). We purchased 9-cis-RA and insulin from Sigma (L'isle d'Abeau, France). Culture media were from Invitrogen (Cergy Pontoise, France) and Biomedia (Boussens, France).

Human skeletal muscle cells. Muscle biopsies (about $100 \mathrm{mg}$ wet weight) were taken under local anaesthesia from the vastus lateralis muscle of lean healthy control subjects with the following characteristics: five men, four women; age $42 \pm 6$ years; BMI 24 $\pm 1 \mathrm{~kg} / \mathrm{m}^{2}$; fasting plasma glucose $5.0 \pm 0.2 \mathrm{mmol} / 1$; fasting plasma insulin $31 \pm 4 \mathrm{pmol} / \mathrm{l}$. None of the control subjects had any familial or personal history of diabetes, dyslipidaemia or hypertension. Biopsies were also taken from moderately obese Type 2 diabetic patients (four men, five women; age $56 \pm 4$ years; BMI $32 \pm 2 \mathrm{~kg} / \mathrm{m}^{2}$; fasting plasma glucose $9.6 \pm 0.9 \mathrm{mmol} / \mathrm{l}$; glycosylated $\mathrm{HbA}_{1} \mathrm{c} 9.1 \pm 0.5 \%$; duration of diabetes $12 \pm 3$ years). None of the control subjects was taking medication except for oral contraceptive agents. For some experiments, muscle cells from healthy lean individuals (three men, two women; age $41 \pm 7$ years; BMI $23 \pm 1 \mathrm{~kg} / \mathrm{m}^{2}$ ) were prepared from biopsies of the erector spinae muscle (about $1 \mathrm{~g}$ ), which were taken during orthopaedic surgical procedures [18]. All subjects gave their informed consent and the protocols were approved by the Ethics Committee of Hospices Civils de Lyon.

The satellite cells were isolated from the muscle biopsies by trypsin digestion and were grown to confluent myoblasts and differentiated into myotubes as previously described in detail $[22,28]$. Experiments were always performed 12 to 16 days after induction of the differentiation process. As indicated previously [28], cells established from Type 2 diabetic patients had the same rate of myoblast growth and fusion into myotubes as cells from control subjects. In agreement with other studies [21, 23, 24, 25], there was no apparent morphological difference between differentiated muscle cells from non-diabetic and diabetic subjects.

The myotubes were pre-incubated for 12 hours in serumfree medium before the addition of drugs or insulin. Wy-14643 ( $1 \mu \mathrm{mol} / \mathrm{l})$ and 9-cis-RA $(1 \mu \mathrm{mol} / \mathrm{l})$ were added either for 6 hours (for studying the regulation of gene expression) or for 24 hours (when investigating the effects on insulin signalling, protein amount and glucose transport). Control incubations with $0.1 \%$ DMSO (vehicle) were always made in parallel.

Quantitation of mRNA levels. Total RNA from differentiated myotubes was prepared using the RNeasy kit (Qiagen, Courtaboeuf, France). The mRNA concentrations of the target genes (insulin receptor, IRS-1, IRS-2, p85 $\alpha$ PI 3-kinase, p110 $\alpha$ PI 3-kinase, p110 $\beta$ PI 3-kinase) were determined by RT-competitive PCR as previously described [11].

Western blots of p $85 \alpha$ PI 3-kinase, protein kinase B, IRS-1 and $I R S$-2. After 24 hours of incubation with $\mathrm{Wy}-14643$ and 9-cis- 
RA, myotubes were homogenised in a PBS lysis buffer containing $1 \%$ Nonidet P-40, $0.5 \%$ sodium deoxycholate and $0.1 \%$ SDS supplemented with a freshly prepared cocktail of protease inhibitors (ICN Pharmaceuticals, Orsay, France). Proteins were separated by SDS-PAGE and transferred to PVDF membrane. Quantification of p85 $\alpha$ PI 3-kinase, PKB, IRS-1 and IRS-2 protein amounts was performed using specific antibodies (Upstate Biotechnology, Lake Placid, N.Y., USA), as described [28].

Phosphatidylinositol 3-kinase activity. After treatment with Wy-14643 and 9cis-RA for 24 hours, myotubes were incubated with insulin $(100 \mathrm{nmol} / \mathrm{l})$ for $10 \mathrm{~min}$ and lysed at $4{ }^{\circ} \mathrm{C}$ in $20 \mathrm{mmol} / \mathrm{l}$ Tris- $\mathrm{HCl}, \mathrm{pH}$ 7.4, $140 \mathrm{mmol} / \mathrm{l} \mathrm{NaCl}, 10 \mathrm{mmol} / \mathrm{l}$ EDTA, 4 mmol/1 $\mathrm{NaVO}_{4}, 100 \mathrm{mmol} / \mathrm{l} \mathrm{NaF}, 10 \mathrm{mmol} / \mathrm{l}$ pyrophosphate, $1 \%$ Nonidet $\mathrm{P}-40$, supplemented with a freshly prepared cocktail of protease inhibitors (ICN). Immunoprecipitation with $\mathrm{p} 85 \alpha$ PI 3-kinase antibody and determination of PI 3-kinase activity on the immunoprecipitate were done as described [28].

Protein kinase $B$ phosphorylation. To estimate PKB activation, the amount of phosphorylated $\mathrm{PKB} \alpha$ on serine 473 was determined. After treatment for 24 hours, cells were incubated with insulin $(100 \mathrm{nmol} / \mathrm{l})$ for $20 \mathrm{~min}$ and then treated as described above. Proteins $(50 \mu \mathrm{g})$ were separated in SDS-PAGE and transferred to PVDF membrane. Phosphorylated $\mathrm{PKB} \alpha$ was identified and quantified using an anti-phospho Akt1/PKB $\alpha$ (Upstate Biotechnology) as described [17]. After analysis, the membranes were stripped and blotted with the PKB to normalise for protein amount.

IRS-1 and IRS-2 tyrosine phosphorylation. After treatment with Wy-14643 and 9cis-RA for 24 hours, myotubes were incubated with insulin $(100 \mathrm{nmol} / \mathrm{l})$ for $10 \mathrm{~min}$ and then lysed in the buffer used for the measurement of PI 3-kinase activity. IRS-1 or IRS-2 were immunoprecipitated with specific antibodies (Upstate Biotechnology). Immunoprecipitates were separated by SDS-PAGE and immunoblotting was performed with a specific anti-phosphotyrosine antibody (PY 99, Santa Cruz Biotechnology, Santa Cruz, Calif., USA). After analysis, the membranes were stripped and blotted with the antibodies against IRS-1 or IRS-2 to normalise for protein amount.

2-Deoxyglucose transport. After treatment with Wy-14643 and 9-cis-RA for 24 hours, myotubes were pre-incubated with or without insulin $(100 \mathrm{nmol} / \mathrm{l})$ for $90 \mathrm{~min}$. Cells were then washed four times with pre-warmed buffer $(150 \mathrm{mmol} / \mathrm{l} \mathrm{NaCl}$, $5 \mathrm{mmol} / \mathrm{l} \mathrm{KCl}, 1.2 \mathrm{mmol} / \mathrm{l} \mathrm{MgSO}_{4}, 1.2 \mathrm{mmol} / \mathrm{l} \mathrm{CaCl}_{2}$, $2.5 \mathrm{mmol} / 1 \mathrm{NaH}_{2} \mathrm{PO}_{4}, 10 \mathrm{mmol} / \mathrm{l}$ HEPES, $\mathrm{pH}$ 7.4) and glucose uptake was measured for $15 \mathrm{~min}$ using $\left[{ }^{3} \mathrm{H}\right] 2$-deoxyglucose (50 $\mu \mathrm{mol} / \mathrm{l}, 14,800 \mathrm{~Bq} /$ well $)$ as described previously [22]. Cytochalasin $(5 \mu \mathrm{mol} / \mathrm{l})$ was used to determine non-specific transport. Results were expressed as pmol of 2-deoxyglucose taken up by the cells per min and per mg of proteins.

Presentation of data. All results in the text and figures are means \pm SE. Statistical significance of the results was determined using paired Student's $t$ tests. The threshold for significance was set at a $p$ value of less than 0.05 .

\section{Results}

Effects of Wy-14643 and 9-cis-RA in skeletal muscle cells from healthy control subjects. Figure 1 shows the

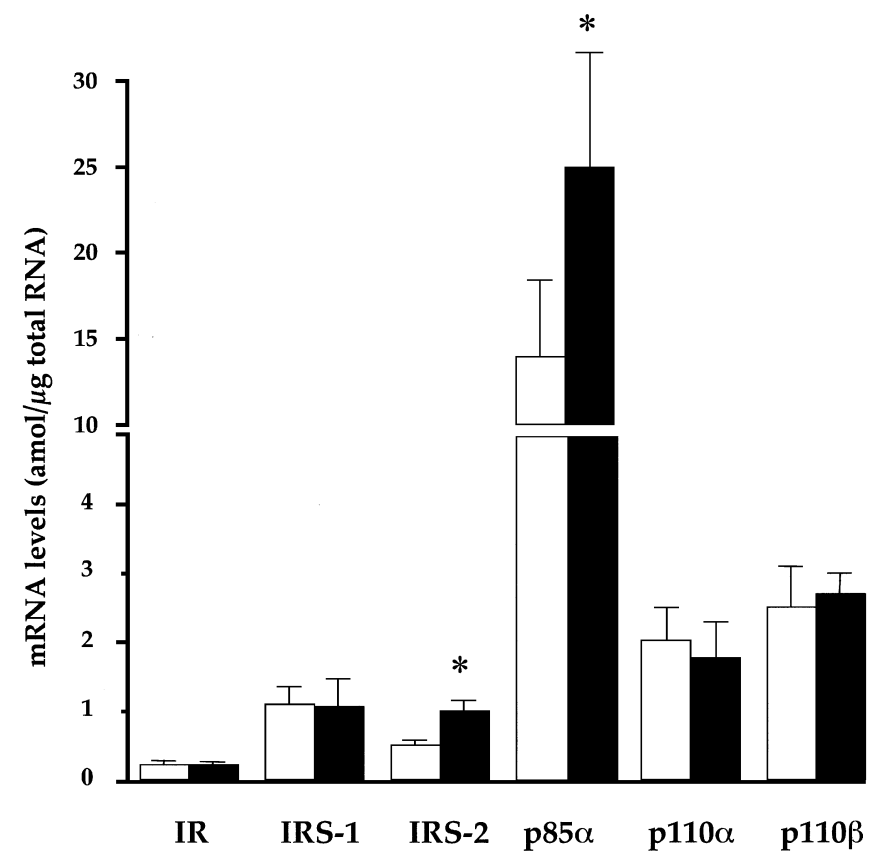

Fig. 1. Regulation of gene expression by Wy-14643 and 9-cisRA in human skeletal muscle cells from healthy subjects. The mRNA levels of insulin receptor (IR), IRS-1, IRS-2, p85 $\alpha$ PI 3-kinase $(\mathrm{p} 85 \alpha), \mathrm{p} 110 \alpha$ PI 3-kinase $(\mathrm{p} 110 \alpha)$ and p110b PI 3-kinase $(\mathrm{p} 110 \beta)$ were determined by quantitative RT-PCR in differentiated myotubes. After overnight incubation without serum, myotubes were treated with $\mathrm{Wy}-14643$ and 9-cis-RA $(1 \mu \mathrm{mol} / 1$ each) or with vehicle $(0.1 \%$ DMSO) for 6 hours. Total RNA was prepared as indicated under "Subjects and methods". The results are presented as absolute mRNA levels in amol/ $\mu \mathrm{g}$ of total RNA. Open bars: untreated cells; black bars: cells treated with Wy-14643 and 9-cis-RA. Data are the means $\pm \mathrm{SE}$ of six independent experiments made with myotubes from five different control subjects. $*, p \leq 0.05$ for treatment with Wy-14643 and 9-cis-RA (paired Student's $t$ test)

effect, in myotubes from control subjects after 6 hours of incubation, of Wy-14643 and 9-cis-RA on mRNA concentrations of the major genes coding proteins involved in insulin signalling. A significant increase in IRS-2 and p85 $\alpha$ PI 3-kinase transcript levels was induced by the drugs, whereas mRNA expression of insulin receptor, IRS- 1 and the $p 110 \alpha$ and $\beta$ subunits of PI 3-kinase was not affected. The change in the mRNA levels was followed by a more than two-fold increase in IRS-2 and p85 $\alpha$ PI 3-kinase protein amounts when incubation was prolonged for 24 hours (Fig. 2). IRS-1 and PKB protein concentrations were not modified by the treatment (Fig. 2).

To assess the consequences of the changes in IRS-2 and p85 $\alpha$ PI 3-kinase expression on insulin signalling, we then investigated the effect of insulin on PI 3-kinase activity and on PKB activation after incubation with Wy-14643 and 9-cis-RA for 24 hours. This treatment did not modify basal PI 3-kinase activity measured in the absence of insulin, but strongly increased the effect of the hormone $(9.4 \pm 0.5$ vs $3.1 \pm$ 1.0-fold increase over basal vs without treatment with 
Anti-IRS-1

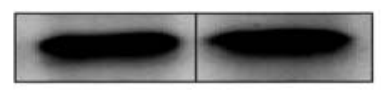

Anti-IRS-2

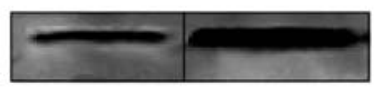

Anti-p85 $\alpha$ PI3K

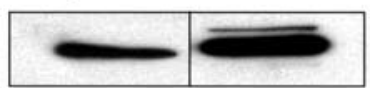

Anti-PKB

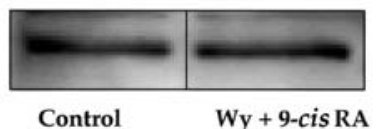

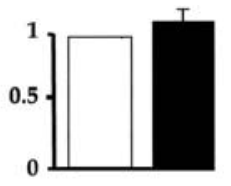
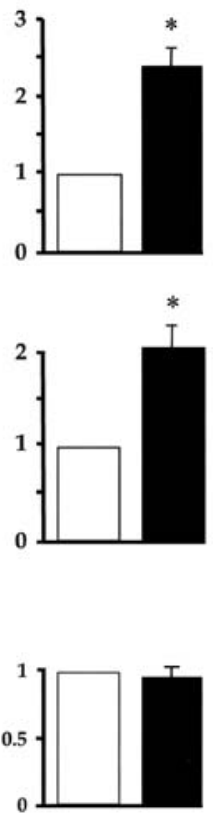

Fig. 2. Effects of Wy-14643 and 9-cis-RA on protein expression of IRS-1, IRS-2, p85 $\alpha$ PI 3-kinase and PKB in myotubes from control subjects. After overnight incubation without serum, myotubes were treated with $\mathrm{Wy}-14643$ and 9-cis-RA $(1 \mu \mathrm{mol} / \mathrm{l}$ each) or vehicle $(0.1 \%$ DMSO) for 24 hours. Immunoblots are shown on left. The results (graphs) are presented as arbitrary units taking the basal level of each protein from untreated cells as 1 unit. Open bars: untreated cells; black bars: cells treated with Wy-14643 and 9-cis-RA. Data are the means \pm SE of three to five independent experiments. ${ }^{*}, p \leq 0.05$ for treatment with Wy-14643 and 9-cis-RA (paired Student's $t$ test)

Wy-14643 and 9-cis-RA, $p=0.025$ ) (Fig. 3a). The phosphorylation of PKB at serine 437 in response to insulin also tended to be enhanced after treatment with Wy-14643 and 9-cis-RA (8.6 \pm 3.1 vs 3.0 \pm 0.8 -fold increase in response to insulin in treated vs untreated myotubes, $p=0.082$ ). Phosphorylation of PKB was not modified in the basal state (Fig. 3b).

We next studied the consequences of this stimulation of insulin signalling on glucose uptake. Figure 4 shows that insulin only increased glucose uptake significantly at a high concentration $(100 \mathrm{nmol} / \mathrm{l})$ in untreated cells. In cells treated with $\mathrm{Wy}-14643$ and 9-cis-RA, the basal rate of glucose uptake was not modified, but a significant stimulation of glucose transport was seen in the presence of $1 \mathrm{nmol} / \mathrm{l}$ of insulin (Fig. 4). The maximal effect of insulin was similar in treated and in untreated cells. Thus the incubation of human muscle cells with Wy-14643 and 9-cis-RA potentiated insulin action on glucose uptake in human skeletal muscle cells.
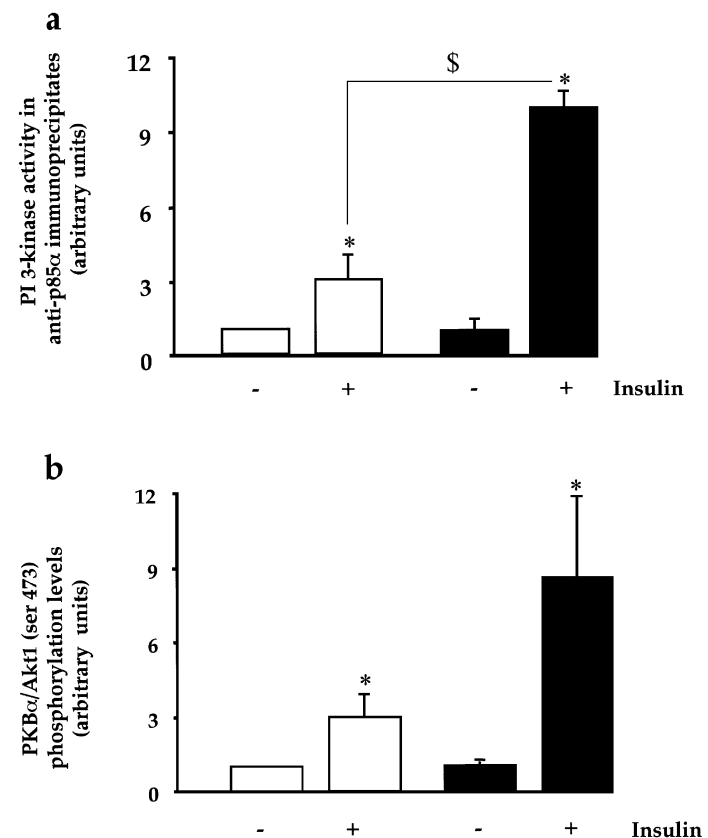

Fig. 3. PI 3-kinase (a) and PKB activation (b) in response to insulin after Wy-14643 and 9-cis-RA treatment in myotubes from control subjects. Myotubes were treated with Wy-14643 and 9-cis-RA ( $1 \mu \mathrm{mol} / \mathrm{l}$ each) or vehicle for 24 hours and incubated with insulin $(100 \mathrm{nmol} / \mathrm{l})$. This was done for $10 \mathrm{~min}$ to measure PI 3-kinase activity and for $20 \mathrm{~min}$ to determine PKB serine 473 phosphorylation as described in "Subjects and methods". Open bars: untreated cells; black bars: cells treated with Wy-14643 and 9-cis-RA. The results are presented as arbitrary units taking basal PI 3-kinase activity and basal phosphorylated PKB of the untreated cells as 1 unit. Data are means \pm SE of three independent experiments. $*, p \leq 0.05$ for the effect of treatment with $\mathrm{Wy}-14643$ and 9-cis-RA (paired Student's $t$ test)

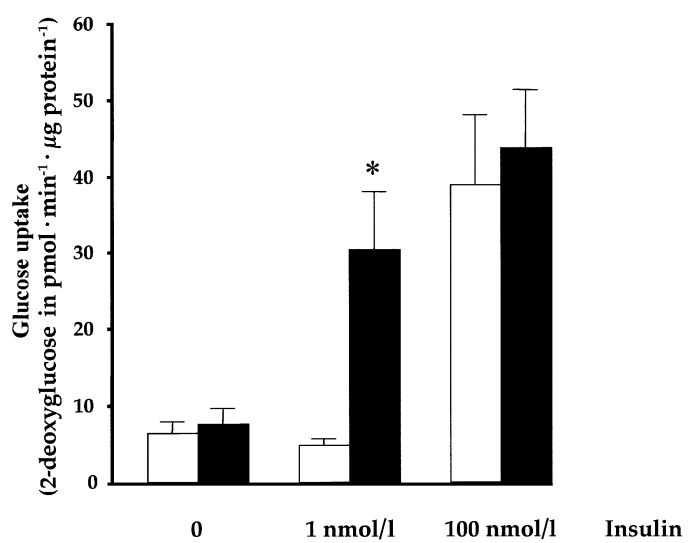

Fig. 4. Effects of Wy-14643 and 9-cis-RA on glucose uptake in myotubes from control subjects. After overnight incubation without serum, myotubes were treated with Wy-14643 and 9-cis-RA ( $1 \mu \mathrm{mol} / \mathrm{l}$ each) or vehicle for 24 hours. Before measuring $\left[{ }^{3} \mathrm{H}\right] 2$-deoxyglucose uptake, cells were pre-incubated for 90 min with insulin $(0,1$ or $100 \mathrm{nmol} / \mathrm{l})$. Open bars: untreated cells; black bars: cells treated with Wy-14643 and 9-cis-RA. Data are means \pm SE of four independent experiments. $*, p \leq 0.05$ for the effect of insulin; $\$, p \leq 0.05$ for the effect of treatment with Wy-14643 and 9-cis-RA (paired Student's $t$ test) 

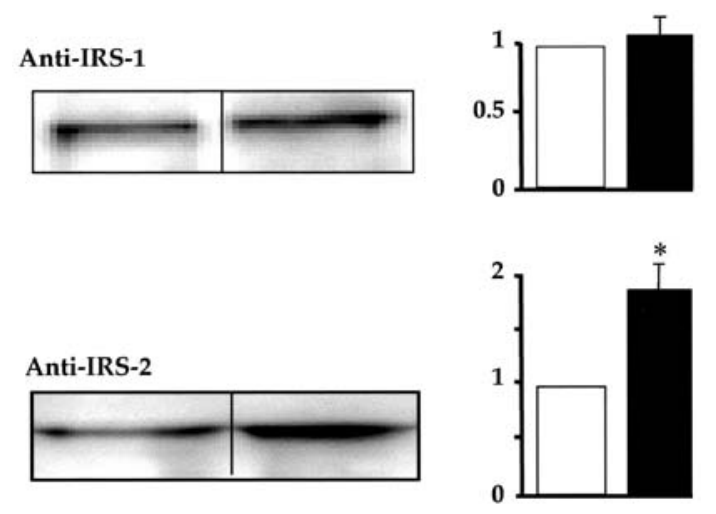

Anti-p85 $\alpha$ PI3K
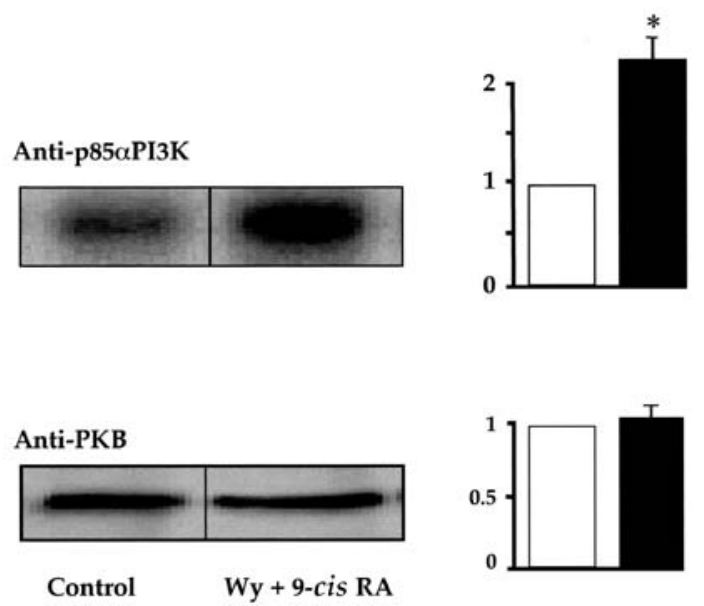

Fig. 5. Effects of Wy-14643 and 9-cis-RA on protein expression of IRS-1, IRS-2, p85 $\alpha$ PI 3-kinase and PKB in myotubes from Type 2 diabetic patients. After overnight incubation without serum, myotubes were treated with Wy-14643 and 9-cis-RA ( $1 \mu \mathrm{mol} / \mathrm{l}$ each) or vehicle $(0.1 \%$ DMSO) for 24 hours. Immunoblots are shown on left. The results (graphs) are presented as arbitrary units taking the basal level of each protein from untreated cells as 1 unit. Open bars: untreated cells; black bars: cells treated with Wy-14643 and 9-cis-RA. Data are the means $\pm \mathrm{SE}$ of three to four independent experiments. ${ }^{*}, p \leq 0.05$ for treatment with Wy-14643 and 9-cis-RA (paired Student's $t$ test)

Effects of Wy-14643 and 9-cis-RA in skeletal muscle cells from Type 2 diabetic patients. Similarly to the results for myotubes from healthy subjects, Figure 5 shows that in cells from diabetic patients treatment with Wy-14643 and 9-cis-RA for 24 hours induced a significant increase in the protein levels of IRS-2 and p $85 \alpha$ PI 3-kinase, without modification of IRS-1 and PKB. In agreement with our previous report [28], there was no apparent difference in the basal levels of any of these proteins in myotubes from non-diabetic and diabetic subjects (data not shown). An increase in the mRNA concentrations of IRS-2 and p85 $\alpha$ PI 3-kinase was observed after 6 hours of treatment with Wy-14643 and 9-cis-RA in cells from diabetic patients ( $n=2$, data not shown), as was the case in myotubes from healthy subjects (Fig. 1).

We next studied the consequences of the rise in IRS-2 and p85 $\alpha$ PI 3-kinase levels on insulin signalling. We found (Fig. 6) that the stimulation of PKB

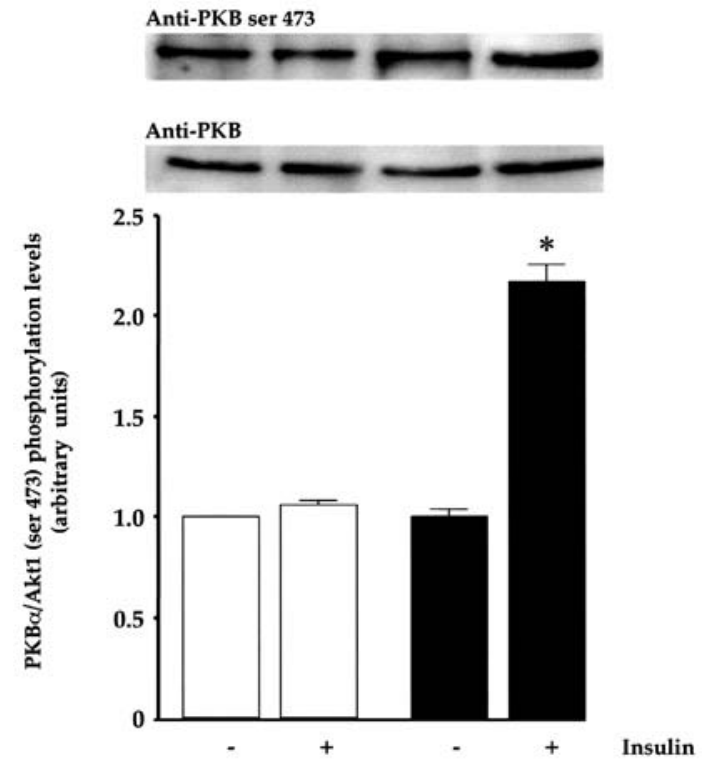

Fig. 6. PKB activation in response to insulin after $\mathrm{Wy}-14643$ and 9-cis-RA treatment in myotubes from Type 2 diabetic patients. Myotubes were treated with Wy-14643 and 9-cis-RA ( $1 \mu \mathrm{mol} / \mathrm{l}$ each) for 24 hours and stimulated for $20 \mathrm{~min}$ by insulin $(100 \mathrm{nmol} / \mathrm{l})$ before determining $\mathrm{PKB} \alpha$ serine 473 phosphorylation as a basis for estimation of PKB activation. Immunoblots are shown above. The results (graph) are presented as arbitrary units taking the basal level of phosphorylated PKB in untreated cells as 1 unit. Open bars: untreated cells; black bars: cells treated with Wy-14643 and 9-cis-RA. Data are the means $\pm \mathrm{SE}$ of three independent experiments. ${ }^{*}, p \leq 0.05$ for the effect of insulin (paired Student's $t$ test)

phosphorylation by insulin was completely blunted in cells from diabetic patients. This observation strengthened the previous finding that insulin did not stimulate PI 3-kinase activity in diabetic myotubes [26, 28]. Interestingly, treatment with Wy-14643 and 9-cis-RA seemed to restore, at least partially, the effect of insulin on PKB phosphorylation. However, this effect remained modest when compared with the potentiation seen in cells from non-diabetic subjects (about 8-fold vs 2-fold increase over basal in response to insulin after treatment in control vs diabetic cells) (Figs. 3 and 6).

As these findings suggested that $\mathrm{Wy}-14643$ and 9-cis-RA treatment were able to increase insulin signalling in muscle cells from Type 2 diabetic patients, we next verified the effect of the treatment on insulininduced glucose transport. Figure 7 shows clearly that the effect of insulin on glucose transport was strongly altered in skeletal muscle cells from diabetic patients. Indeed, no significant effect of insulin on the rate of 2-deoxyglucose uptake was seen, even in the presence of $100 \mathrm{nmol} / \mathrm{l}$ of insulin (Fig. 7). Surprisingly, treatment with Wy-14643 and 9-cis-RA for 24 hours did not improve the response to insulin, but did produce a 3.5 -fold increase $(p<0.001)$ in the basal rate of glucose uptake (Fig. 7). These results indicated that despite a similar induction of IRS-2 and p85 $\alpha$ PI 


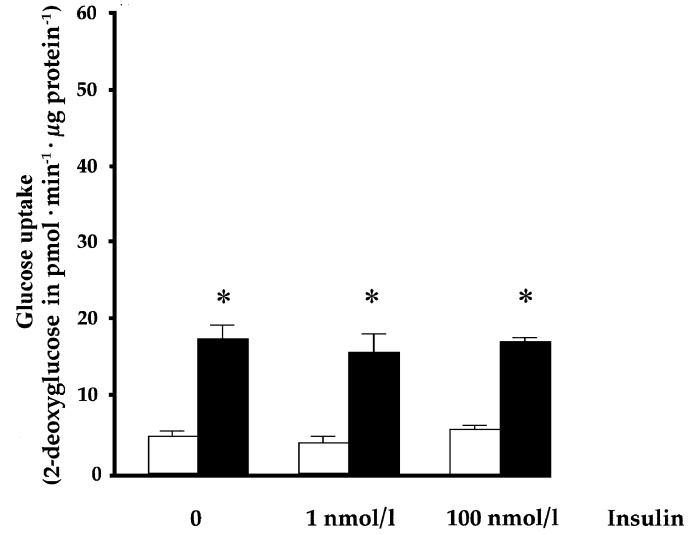

Fig. 7. Effects of Wy-14643 and 9-cis-RA on glucose uptake in muscle cells from Type 2 diabetic patients. Myotubes treated or not with Wy-14643 and 9-cis-RA (1 $\mu \mathrm{mol} / \mathrm{l}$ each) for 24 hours were pre-incubated for $90 \mathrm{~min}$ with insulin $(0,1$ or $100 \mathrm{nmol} / \mathrm{l})$ before measuring $\left[{ }^{3} \mathrm{H}\right] 2$-deoxyglucose uptake as described in "Subjects and methods". Open bars: untreated cells; black bars: cells treated with Wy-14643 and 9-cis-RA. Data are the means $\pm \mathrm{SE}$ of four independent experiments. $*, p \leq 0.05$ for the effect of the treatment with $\mathrm{Wy}-14643$ and 9-cis-RA (paired Student's $t$ test)

3-kinase protein expression, the effect of $\mathrm{Wy}-14643$ and 9-cis-RA treatment was different in muscle cells from control subjects than it was in cells from diabetic subjects.

To get more insight into this differential effect, we further investigated the upstream steps of the insulin signalling cascade. In agreement with previous results [28], we found that insulin promoted a two-fold increase in the amount of IRS-1 phosphorylated on tyrosine residues in myotubes from control subjects, and that this effect was completely blunted in cells prepared from Type 2 diabetic patients (Fig. 8a). Tyrosine phosphorylation of IRS-1 is required for it to interact with p85 $\alpha$ PI 3-kinase, with subsequent activation of PI 3-kinase [8, 9]. Figure $8 \mathrm{~b}$ shows the amount of p85 $\alpha$ PI 3-kinase associated with IRS-1 in the basal state or after insulin stimulation. In agreement with the lack of insulin-induced tyrosine phosphorylation, insulin had virtually no effect on the association of p85 $\alpha$ PI 3-kinase with IRS-1 in muscle cells from diabetic patients, but promoted a 2.5 -fold increase in this association in cells from control subjects. Treatment with Wy-14643 and 9-cis-RA did not modify basal or insulin-stimulated tyrosine phosphorylation of IRS-1 in myotubes from control or diabetic subjects (Fig. 8a). However, a higher association of p85 $\alpha$ PI 3-kinase with IRS-1 was noticeable in the presence of insulin, mostly in cells from control subjects (Fig. 8b), probably reflecting the increased amount of p85 $\alpha$ PI 3-kinase after treatment with Wy-14643 and 9-cis-RA (Figs. 2 and 5).

In contrast to the results for IRS-1, insulin increased tyrosine phosphorylation of IRS-2 (Fig. 9a)
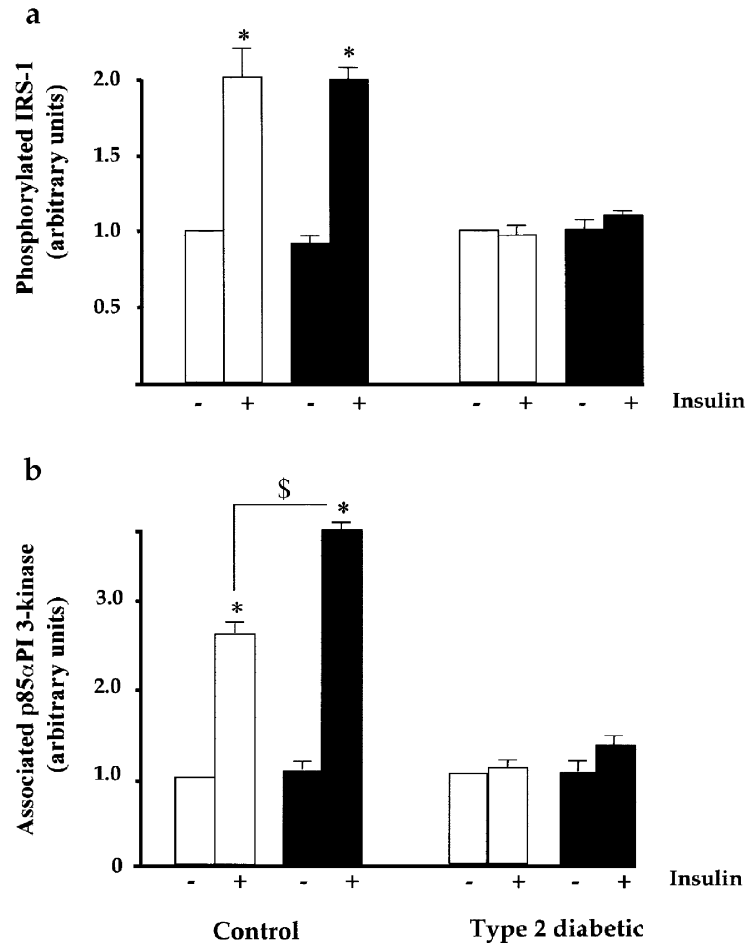

Fig. 8. Effects of Wy-14643 and 9-cis-RA on IRS-1 tyrosine phosphorylation (a) and association with p85 $\alpha$ PI 3-kinase (b). After treatment (a) with insulin for $10 \mathrm{~min}(100 \mathrm{nmol} / \mathrm{l})$, cells were lysed, IRS-1 protein was immunoprecipitated and tyrosine phosphorylation was determined by western blot using an anti-phosphotyrosine antibody (see "Subjects and methods"). The results are presented as arbitrary units taking the basal phosphorylation of IRS-1 in untreated cells from control or Type 2 diabetic subjects respectively as 1 unit. Open bars: untreated cells; black bars: cells treated with Wy-14643 and 9-cis-RA. Data are means \pm SE of three independent experiments made with myotubes from three different control subjects and three different Type 2 diabetic patients. *, $p \leq 0.05$ for the effect of insulin (paired Student's $t$ test). b. After cell treatment as in (a), the amount of p85 $\alpha$ PI 3-kinase was determined by western blot using an anti-p85 $\alpha$ PI 3-kinase antibody. The results are presented as arbitrary units taking the basal amount of $\mathrm{p} 85 \alpha$ PI 3-kinase associated with IRS-1 in untreated cells from control or Type 2 diabetic subjects respectively as 1 unit. Open bars: untreated cells; black bars: cells treated with Wy14643 and 9-cis-RA. Data are means \pm SE of three independent experiments made with myotubes from three different control subjects and three different Type 2 diabetic patients. $*, p \leq 0.05$ for the effect of insulin; $\$, p \leq 0.05$ for the effect of treatment with Wy-14643 and 9-cis-RA (paired Student's $t$ test)

and the association of p85 $\alpha$ PI 3-kinase with IRS-2 (Fig. 9b) in myotubes both from control and from diabetic subjects. Treatment with Wy-14643 and 9-cisRA increased the amount of IRS-2 phosphorylated on tyrosine residues in the basal state and during insulin stimulation (Fig. 9a). It also increased the association of $\mathrm{p} 85 \alpha$ PI 3-kinase with IRS-2 in response to insulin (Fig. 9b). These effects occurred in myotubes prepared from non-diabetic and diabetic subjects. 

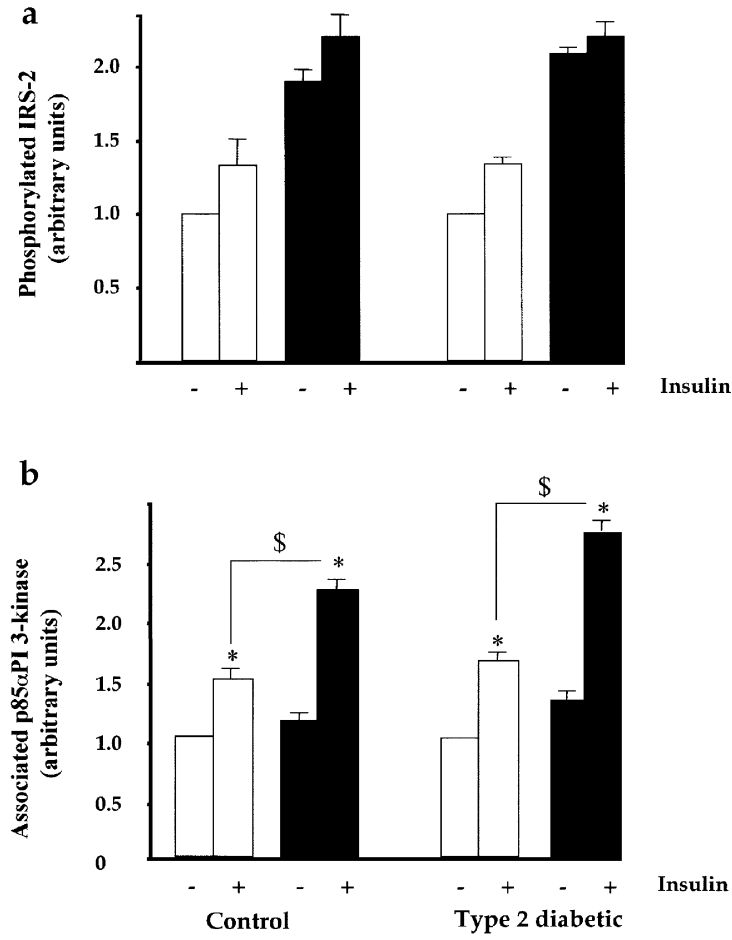

Fig. 9. Effects of Wy-14643 and 9-cis-RA on IRS-2 tyrosine phosphorylation and association with p $85 \alpha$ PI 3-kinase. Procedures and other details as in Figure 8, but using IRS-2 immunoprecipitates to determine IRS-2 phosphorylation (a) and p85 $\alpha$ PI 3-kinase association (b)

\section{Discussion}

The present study demonstrated that treatment of human skeletal muscle cells with a combination of Wy-14643 and 9-cis-RA increased insulin signalling and potentiated insulin action on glucose uptake in skeletal muscle cells from healthy subjects. These effects were associated with an induction of IRS-2 and p85 $\alpha$ PI 3-kinase mRNA and protein expression leading to increased insulin stimulation of PI 3-kinase activity and PKB phosphorylation. The same treatment in myotubes from Type 2 diabetic patients also induced IRS-2 and p85 $\alpha$ PI 3-kinase protein levels but failed to restore insulin stimulation of glucose transport. The lack of insulin effect on glucose transport paralleled a strong defect in tyrosine phosphorylation of IRS- 1 and in the association of p $85 \alpha$ PI 3-kinase with IRS-1. Treatment of myotubes from Type 2 diabetic patients with Wy-14643 and 9-cis-RA did not correct these alterations, despite a marked stimulation of the effect of insulin on tyrosine phosphorylation of IRS-2 and on its association with p85 $\alpha$ PI 3-kinase.

Several studies have demonstrated that primary cultures of muscle cells established from Type 2 diabetic patients display defects that are similar to those observed in vivo in skeletal muscle, including a reduced stimulation of glucose uptake and glycogen synthesis $[21,23,24,25,26,27]$. Similarly to what is classically found in skeletal muscle biopsies [29], it was demonstrated that protein levels of the glucose transporter Glut4 are not different in myotubes from control subjects than they are in myotubes from Type 2 diabetic subjects [23]. In agreement with this study, we also found similar levels of Glut 4 mRNA in muscle cells from healthy subjects and Type 2 diabetic patients (data not shown). Although it is known that cultured muscle cells expressed high levels of Glut1 and lower amounts of Glut4 than mature skeletal muscle $[23,25,30]$, it was recently demonstrated by means of the photolabelling method that insulin-stimulated glucose uptake is mainly mediated by Glut 4 in this cell system [30].

In addition to reduced glucose transport, myotubes prepared from Type 2 diabetic patients display a defective stimulation of PI 3-kinase activity by insulin $[26,28]$ and reduced stimulation by insulin of the tyrosine phosphorylation of IRS-1 [26, 28]. We confirmed this observation in the present work. Because a similar dysfunction in the IRS-1-dependent PI 3-kinase pathway has also been found in vivo in the skeletal muscle of Type 2 diabetic patients $[3,4,5,6$, 7], the primary culture of human myotubes is a suitable and powerful model for investigating the possible causes of insulin resistance and testing the effect of agents designed to improve insulin action in human muscle.

In agreement with previous reports [21, 23, 25], we found that the action of insulin on glucose transport is profoundly altered in myotubes from Type 2 diabetic patients. This defect occurred in the presence of a marked alteration in the stimulation by insulin of the IRS-1/PI 3-kinase pathway, whereas the activation of PI 3-kinase via IRS-2 appeared marginally affected in muscle cells from diabetic subjects [28]. Moreover, induction of IRS-2 and improvement of insulininduced IRS-2 tyrosine phosphorylation and its interaction with PI 3-kinase did not restore the effect of insulin on glucose transport. Taken together, these results suggest that induction of the IRS-2-dependent PI 3-kinase pathway cannot compensate for altered function of IRS-1 in cultured human muscle cells. In addition, these data suggest that the IRS-2/PI 3-kinase pathway does not play a major role in the effect of insulin on glucose uptake in muscle cells. This hypothesis, however, needs to be supported by additional data. Indeed, it cannot be ruled out that the lack of effect of insulin on glucose transport in myotubes from diabetic patients resulted from additional defects, downstream of the signalling cascade.

The translocation of the vesicles containing glucose transporters to the plasma membrane is a complex process, requiring a large number of regulatory proteins [31]. Alterations in the expression levels of some of these key proteins, including the transporters themselves, could also contribute to the observed defect in transport of glucose. Because Wy-14643 and 9-cis-RA 
did not restore the action of insulin on glucose transport, our data suggest that these molecules did not directly affect the expression of such key regulatory proteins. However, as basal glucose uptake was enhanced in the myotubes from Type 2 diabetic patients after the treatment with $\mathrm{Wy}-14643$ and 9-cis-RA, it is possible that these substances have an effect on some genes involved in the regulation of glucose transport. Additional work is therefore required to define more accurately the possible impact of these drugs on the glucose transporter trafficking system.

We have previously reported that the reduced ability of insulin to increase IRS-1 tyrosine phosphorylation in cultured muscle cells from diabetic subjects is probably the result of an increased level of IRS-1 phosphorylation on serine residues [28]. We found that the phosphorylation of IRS-1 on serine 636 was significantly higher in myotubes from Type 2 diabetic patients [28], and previous experiments with IRS-1 protein bearing a mutation of serine 636 indicated that this residue probably plays a role in the regulation of insulin-induced interaction between IRS-1 and PI 3-kinase [32]. The possibility that serine phosphorylation of IRS-1 plays a role in insulin resistance has been pointed out in recent years, particularly to explain the link between altered fatty acid metabolism in skeletal muscle and insulin resistance [33, 34, 35]. It has been proposed that long-chain acyl-CoA and diacylglycerol accumulation in the muscle might inhibit insulin signalling through phosphorylation of IRS-1 serine/threonine by protein kinase $\mathrm{C}$ (PKC)s or other kinases $[33,34,35,36]$. To date, however, there is no clear demonstration that this mechanism occurs in human muscle cells and particularly in cells from people with Type 2 diabetes. Our present data suggest that the altered stimulation of the IRS-1/PI 3-kinase pathway observed in myotubes from diabetic patients was probably not directly related to fatty acid metabolism. In fact, it has been shown that activation of PPAR $\alpha$ reduces muscle triglycerides and long-chain acyl CoA accumulation in vivo in rats [37] and increases fatty acid oxidation in human skeletal muscle cells [38]. These metabolic effects would lead to lower PKC activation and reduction of serine phosphorylation of IRS-1, thereby improving IRS-1 tyrosine phosphorylation and insulin signalling. In the muscle cells from Type 2 diabetic patients, incubation with Wy-14643 (an activator of PPAR $\alpha$ ) did not modify tyrosine phosphorylation of IRS-1, suggesting that serine phosphorylation was not affected under our experimental conditions. Further work is required to verify this hypothesis.

Wy-14643 and 9-cis-RA are well characterised ligands of nuclear receptors, and it is likely that these molecules acted mainly through the regulation of gene expression in myotubes. Wy-14643 is an efficient activator of PPAR $\alpha$ and 9-cis-RA is a ligand of RXR. These two receptors form a heterodimer that binds specific sequences in the promoter region of their target genes and modulates their transcription [39]. However, it should be noted that while Wy-14643 is an efficient activator of PPAR $\alpha$ in rodents, it is reported to be less potent in activating human PPAR $\alpha$ [40, 41]. We are currently investigating the effects of other activators of PPAR $\alpha$ to confirm its implication in muscle cells. It has also been demonstrated that IRS-2 [42] and p85 $\alpha$ PI 3-kinase [17] gene expression can be induced by activation of PPAR $\gamma$ in human adipocytes and that this effect leads to improved insulin signalling [17]. The ligands of PPAR $\gamma$ were inefficient in myotubes, probably due to the low expression level of this nuclear receptor in muscle [18]. It appears therefore that the transcription of the genes encoding IRS-2 and p85 $\alpha$ PI 3-kinase could be activated by different PPAR/RXR heterodimers. The tissue-specific action of PPAR $\alpha$ or PPAR $\gamma$ may depend on the relative abundance of these nuclear receptors or on the preferential expression of co-factors. Taken together, these observations suggest that drugs with dual action on PPAR $\alpha$ and PPAR $\gamma$ might be able to induce the IRS-2/PI 3-kinase signalling pathway in parallel in adipose tissue and in skeletal muscle.

Finally, it is interesting to note that 9-cis-RA alone was able to reproduce, at least in part, the effects on gene expression, as previously shown for p85 $\alpha$ PI 3-kinase [18]. This suggests that rexinoids and activation of RXR are potentially able to affect insulin signalling in human muscle cells, in agreement with experiments in rodents showing that animals treated with RXR activators have improved insulin sensitivity [20].

In summary, using primary cultures of skeletal muscle cells, we have investigated the mechanism of action of nuclear receptor activators known to improve insulin action in rodent models. Incubation of human muscle cells with a combination of Wy-14643 (activator of PPAR $\alpha$ ) and 9-cis-RA (activator of RXR) increased IRS-2 and p85 $\alpha$ PI 3-kinase expression in cells from non-diabetic and Type 2 diabetic subjects. In cells from control subjects, the treatment led to increased PI 3-kinase activity, PKB phosphorylation and glucose uptake in the presence of insulin. Myotubes from Type 2 diabetic patients displayed an important alteration in the stimulation by insulin of the IRS-1/PI 3-kinase pathway and a blunted stimulation of glucose transport in response to insulin. The treatment with Wy-14643 and 9-cis-RA did not restore these defects but increased the basal rate of glucose uptakes. Taken together, these results demonstrated that increasing the IRS-2/PI 3-kinase pathway did not overcome the impaired stimulation of the IRS-1-dependent pathway in muscle cells. They also suggest that the defective activation of PI 3-kinase by IRS-1 plays an important role in the altered stimulation of glucose uptake by insulin in myotubes from Type 2 diabetic patients. 
Acknowledgements. This work was supported by research grants from the Institut National de la Santé et de la Recherche Médicale and Institut de Recherche Servier. K. Bouzakri is recipient of a research grant from the Association Française de Nutrition/Société de Nutrition de Langue Française (AFN/SNDLF). The authors thank the Centre Commun d'Imagerie Laennec (CeCIL) for access to the phospho- and fluoroImagers.

\section{References}

1. DeFronzo RA (1992) Pathogenesis of type 2 (non-insulin dependent) diabetes mellitus: a balanced overview. Diabetologia 35:389-397

2. Yki-Jarvinen H (1995) Role of insulin resistance in the pathogenesis of NIDDM. Diabetologia 38:1378-1388

3. Bjornholm M, Kawano Y, Lehtihet M, Zierath JR (1997) Insulin receptor substrate-1 phosphorylation and phosphatidylinositol 3-kinase activity in skeletal muscle from NIDDM subjects after in vivo insulin stimulation. Diabetes 46:524-527

4. Kim YB, Nikoulina SE, Ciaraldi TP, Henry RR, Kahn BB (1999) Normal insulin-dependent activation of Akt/protein kinase $\mathrm{B}$, with diminished activation of phosphoinositide 3-kinase, in muscle in type 2 diabetes. J Clin Invest 104:733-741

5. Cusi K, Maezono K, Osman A et al. (2000) Insulin resistance differentially affects the PI3-kinase- and MAP kinasemediated signaling in human muscle. J Clin Invest 105:311320

6. Krook A, Bjornholm M, Galuska D et al. (2000) Characterization of signal transduction and glucose transport in skeletal muscle from type 2 diabetic patients. Diabetes 49:284-292

7. Pratipanawatr W, Pratipanawatr T, Cusi K et al. (2001) Skeletal muscle insulin resistance in normoglycemic subjects with a strong family history of type 2 diabetes is associated with decreased insulin-stimulated insulin receptor substrate-1 tyrosine phosphorylation. Diabetes 50:25722578

8. Kahn CR (1994) Insulin action, diabetogenes, and the cause of type II diabetes. Diabetes 43:1066-1084

9. Shepherd PR, Withers DJ, Siddle K (1998) Phosphoinositide 3-kinase: the key switch mechanism in insulin signalling. Biochem J 333:471-490

10. Zierath JR, Krook A, Wallberg-Henriksson H (2000) Insulin action and insulin resistance in human skeletal muscle. Diabetologia 43:821-835

11. Ducluzeau PH, Perretti N, Laville M et al. (2001) Regulation by insulin of gene expression in human skeletal muscle and adipose tissue. Evidence for specific defects in type 2 diabetes. Diabetes 50:1134-1142

12. Lefai E, Roques M, Vega N, Laville M, Vidal H (2001) Expression of the splice variants of the p85alpha regulatory subunit of phosphoinositide 3-kinase in muscle and adipose tissue of healthy subjects and type 2 diabetic patients. Biochem J 15:117-126

13. Goodyear LJ, Giorgino F, Sherman LA, Carey J, Smith RJ, Dohm GL (1995) Insulin receptor phosphorylation, insulin receptor substrate-1 phosphorylation, and phosphatidylinositol 3-kinase activity are decreased in intact skeletal muscle strips from obese subjects. J Clin Invest 95:2195-2204

14. Terauchi Y, Tsuji Y, Satoh S et al. (1999) Increased insulin sensitivity and hypoglycaemia in mice lacking the p85 alpha subunit of phosphoinositide 3-kinase. Nat Genet 21:230-235
15. Miyake K, Ogawa W, Matsumoto M, Nakamura T, Sakaue H, Kasuga M (2002) Hyperinsulinemia, glucose intolerance, and dyslipidemia induced by acute inhibition of phosphoinositide 3-kinase signaling in the liver. J Clin Invest 110:1483-1491

16. Olefsky JM (2000) Treatment of insulin resistance with peroxisome proliferator-activated receptor gamma agonists. J Clin Invest 106:467-472

17. Rieusset J, Chambrier C, Bouzakri K et al. (2001) The expression of the p85alpha subunit of phosphatidylinositol 3 -kinase is induced by activation of the peroxisome proliferator-activated receptor gamma in human adipocytes. Diabetologia 44:544-554

18. Rieusset J, Roques M, Bouzakri K, Chevillotte E, Vidal H (2001) Regulation of p85alpha phosphatidylinositol-3kinase expression by peroxisome proliferator-activated receptors (PPARs) in human muscle cells. FEBS Lett 502:98-102

19. Guerre-Millo M, Gervois P, Raspe E et al. (2000) Peroxisome proliferator-activated receptor alpha activators improve insulin sensitivity and reduce adiposity. J Biol Chem 275:16638-16642

20. Mukherjee R, Davies PJ, Crombie DL et al. (1997) Sensitization of diabetic and obese mice to insulin by retinoid $\mathrm{X}$ receptor agonists. Nature 386:407-410

21. Henry RR, Abrams L, Nikoulina S, Ciaraldi TP (1995) Insulin action and glucose metabolism in nondiabetic control and NIDDM subjects. Comparison using human skeletal muscle cell cultures. Diabetes 44:936-946

22. Roques M, Vidal H (1999) A phosphatidylinositol 3-kinase/ p70 ribosomal S6 protein kinase pathway is required for the regulation by insulin of the p85alpha regulatory subunit of phosphatidylinositol 3-kinase gene expression in human muscle cells. J Biol Chem 274:34005-34010

23. Ciaraldi TP, Abrams L, Nikoulina S, Mudaliar S, Henry RR (1995) Glucose transport in cultured human skeletal muscle cells. Regulation by insulin and glucose in nondiabetic and non-insulin-dependent diabetes mellitus subjects. J Clin Invest 96:2820-2827

24. Henry RR, Ciaraldi TP, Abrams-Carter L, Mudaliar S, Park KS, Nikoulina SE (1996) Glycogen synthase activity is reduced in cultured skeletal muscle cells of non-insulindependent diabetes mellitus subjects. Biochemical and molecular mechanisms. J Clin Invest 98:1231-1236

25. Jackson S, Bagstaff SM, Lynn S, Yeaman SJ, Turnbull DM, Walker M (2000) Decreased insulin responsiveness of glucose uptake in cultured human skeletal muscle cells from insulin-resistant nondiabetic relatives of type 2 diabetic families. Diabetes 49:1169-1177

26. Nikoulina SE, Ciaraldi TP, Carter L, Mudaliar S, Park KS, Henry RR (2001) Impaired muscle glycogen synthase in type 2 diabetes is associated with diminished phosphatidylinositol 3-kinase activation. J Clin Endocrinol Metab 86:4307-4314

27. Gaster M, Petersen I, Hojlund K, Poulsen P, Beck-Nielsen $\mathrm{H}$ (2002) The diabetic phenotype is conserved in myotubes established from diabetic subjects: evidence for primary defects in glucose transport and glycogen synthase activity. Diabetes 51:921-927

28. Bouzakri K, Roques M, Gual P et al. (2003) Reduced activation of phosphatidylinositol-3-kinase and increased serine 636 phosphorylation of insulin receptor substrate-1 in primary culture of skeletal muscle cells from patients with type 2 diabetes. Diabetes 52:1319-1325

29. Garvey WT, Maianu L, Hancock JA, Golichowski AM, Baron A (1992) Gene expression of GLUT4 in skeletal muscle from insulin-resistant patients with obesity, IGT, GDM, and NIDDM. Diabetes 41:465-475 
30. Al-Khalili L, Chibalin AV, Kannisto K et al. (2003) Insulin action in cultured human skeletal muscle cells during differentiation: assessment of cell surface GLUT4 and GLUT1 content. Cell Mol Life Sci 60:991-998

31. Khan AH, Pessin JE (2002) Insulin regulation of glucose uptake: a complex interplay of intracellular signalling pathways. Diabetologia 45:1475-1483

32. Mothe I, Van Obberghen E (1996) Phosphorylation of insulin receptor substrate-1 on multiple serine residues, 612, 632, 662, and 731, modulates insulin action. J Biol Chem 271:11222-11227

33. McGarry JD (2002) Dysregulation of fatty acid metabolism in the etiology of type 2 diabetes. Diabetes 51:7-18

34. Shulman GI (2000) Cellular mechanisms of insulin resistance. J Clin Invest 102:171-176

35. Kelley DE, Goodpaster BH, Storlien L (2002) Muscle triglyceride and insulin resistance. Annu Rev Nutr 22:325346

36. Yu C, Chen Y, Cline GW et al. (2002) Mechanism by which fatty acids inhibit insulin activation of insulin receptor substrate-1 (IRS-1)-associated phosphatidylinositol 3-kinase activity in muscle. J Biol Chem 277:50230-50236

37. Ye JM, Doyle PJ, Iglesias MA, Watson DG, Cooney GJ, Kraegen EW (2001) Peroxisome proliferator-activated receptor (PPAR)-alpha activation lowers muscle lipids and improves insulin sensitivity in high fat-fed rats: comparison with PPAR-gamma activation. Diabetes 50:411-417

38. Muoio DM, Way JM, Tanner CJ et al. (2002) Peroxisome proliferator-activated receptor-alpha regulates fatty acid utilization in primary human skeletal muscle cells. Diabetes 51:901-909

39. Desvergne B, Wahli W (1999) Peroxisome proliferatoractivated receptors: nuclear control of metabolism. Endocr Rev 20:649-688

40. Mukherjee R, Jow L, Noonan D, McDonnell DP (1994) Human and rat peroxisome proliferator-activated receptors (PPARs) demonstrate similar tissue distribution but different responsiveness to PPAR activators. J Steroid Biochem Mol Biol 51:157-166

41. Keller H, Devchand PR, Perroud M, Wahli W (1997) PPAR alpha structure-function relationships derived from species-specific differences in responsiveness to hypolipidemic agents. Biol Chem 378:651-655

42. Smith U, Gogg S, Johansson A, Olausson T, Rotter V, Svalstedt B (2001) Thiazolidinediones (PPARgamma agonists) but not PPARalpha agonists increase IRS-2 gene expression in 3T3-L1 and human adipocytes. FASEB J 15:215-220 